\title{
Method of Addition of Bromocriptine to the Drug Regime of Patients with Advanced Parkinson's Disease
}

\author{
J. DAVID GRIMES and MOHAMED N. HASSAN
}

SUMMARY: Using a method of a gradual increase of bromocriptine with a concomitant reduction of Sinemet $\Theta$ (levodopa $250 \mathrm{mg}+$ carbidopa $25 \mathrm{mg}$ ), 19 patients with advanced Parkinson's disease have been treated for periods of up to 22 months and 16 of them have shown improvements of varying degrees. Eighteen patients were able to tolerate bromocriptine addition. with early transient adverse effects occur-

RÉSUMÉ: En utilizant un régime d'augmentation gradual de Bromocriptine, avec une réduction simultanée de Sinemet (levodopa $250 \mathrm{mg}$ et carbidopa $25 \mathrm{mg}$ ), 16 des 19 patients traités pour jusqu'a 22 mois, on démontrés une amélioration variable.

Contrairement à d'autres reportages scientifiques, il fût nécéssaire d'abandonner ring in seven cases. In contrast to several previously reported studies, it was found necessary to withdraw bromocriptine in only one case.

With the drugs currently available, bromocriptine has a role in the management of patients with advanced Parkinson's disease. The method described here may allow a greater number of patients to be given a trial with this drug.

le Bromocriptine dans un CAS seulement. En plus des médicaments présentement disponibles pour le traitement des formes avançées de la maladie de Parkinson, il semble que le Bromocriptine peut jouer un rôle important. Cette méthode permet l'essai de ce médicament chez un plus grand nombre de patients.
From the Parkinson's Disease Clinic, Department of Neurology, Ottawa Civic Hospital and the University of Ottawa.

Presented in part at the XIV Canadian Congress of Neurological Sciences, Halifax, Nova Scotia, Canada June 1979.

Reprint requests to: Dr, J.D. Grimes, 1081 Carling Avenue, Ottawa, Ontario, Canada K IY 4G2.

\section{INTRODUCTION}

Bromocriptine is an ergot polypeptide which acts as a dopaminergic agonist with both pre and post synaptic effects. A number of studies including those of Calne et al. (1978); Pearce and Pearce (1978); Rascol et al. (1979); Lieberman et al. (1979); and Fahn et al. (1979) have shown that bromocriptine is an effective agent in the treatment of Parkinson's disease. Most reports have suggested that the group most likely to benefit are those patients with ON-OFF phenomena.

Fahn et al. (1979) have suggested recently that bromocriptine be added to the drugs of any Parkinsonian patient either with intractable symptoms despite optimum levodopa therapy or with adverse effects from levodopa. Most patients now started on bromocriptine will have it added to their already existing Parkinsonian drug regime. This method has given better results. It has also allowed lower effective doses of bromocriptine, an added advantage, when one considers the relatively high cost of bromocriptine.

\section{PATIENT SELECTION}

Nineteen patients (seven men \& 12 women) ranging in age from 46 to 79 years with Parkinson's disease for periods of 6 to 15 years were treated with bromocriptine. The majority of these patients had been followed for many years.

All the patients had advanced disease which was not controlled with multiple adjustments of all available medication. Fifteen of the 19 patients were started on bromocriptine for fluctuations in daily performance (ON-OFF phenomena) while the remaining four patients had advanced disease with severe bradykinesia, tremor, and rigidity. Fourteen of the 
19 already had variable degrees of slowness of mentation.

All of the patients were on Sinemet. Eleven patients were also on other medications; three were on benztropine, three were on amantadine, and five were on both.

\section{METHOD}

Before starting bromocriptine all patients were carefully documented clinically during four clinic visits in the previous month. They were followed at two to four week intervals during the bromocriptine induction phase, and every one to three months thereafter. As many of the patients had slowness of mentation, written instructions were given to a reliable relative or nurse. Telephone calls were often necessary between clinic visits. Routine hematological and serum biochemical studies, urinalyses and electrocardiograms were done before starting bromocriptine and at regular intervals during its administration. Female patients had regular pelvic examinations.

Tablets of $2.5 \mathrm{mg}$ and capsules of $10 \mathrm{mg}$ of bromocriptine were used. The patients were initially started on 2.5 $\mathrm{mg}$ twice daily but if they were frail or confused a lower dosage of $1.25 \mathrm{mg}$ was initiated. The dose was increased at a rate of $2.5 \mathrm{mg}$ or less every three days to a dose of $10 \mathrm{mg}$ three times daily. At this point the $10 \mathrm{mg}$ capsules were started and the $2.5 \mathrm{mg}$ tablets were used for further slow increases above $30 \mathrm{mg}$ daily to a maximum of 60 mg per day.

As the bromocriptine dosage was being increased, an attempt was made to reduce Sinemet by $1 / 4$ tablet every seven days over the first three to four weeks. Patients taking Sinemet every two to three hours (because of the $\mathrm{ON}$ OFF phenomena) were instructed to take Sinemet and bromocriptine together on a tid or qid schedule. The bromocriptine increases were stopped if significant improvement occurred or if adverse effects developed. Therapeutic bromocriptine dosages were achieved over four to 16 weeks (average 9.8).

The following additional drug manipulations proved helpful:

(a) When dyskinesia increased, a reduction of Sinemet while continuing to increase bromocriptine often arrested or decreased the dyskinesia.

(b) When dyskinesia decreased, but rigidity and bradykinesia increased, then the dose of Sinemet was found to have been reduced too much. A cautious increase of $1 / 4$ or $1 / 2$ tablet of Sinemet once or twice daily improved the rigidity and bradykinesia.

(c) Initial failure to respond to bromocriptine or the development of confusion was best managed by a major Sinemet reduction of 250 $375 \mathrm{mg}$ per day.

(d) Withdrawal of amantadine led to clinical deterioration; the drug was therefore continued in all cases. Some patients tolerated withdrawal of benztropine with improvement of mentation.

(e) Using the tablet preparation of levodopa with a dopa decarboxylase inhibitor, rather than a capsule preparation, gave much greater flexibility in dosage adjustment.

\section{RESULTS}

Sixteen of the patients have been on bromocriptine from 12 to 22 months. Two patients have been treated for four months and the drug was discontinued in one patient.

Sixteen of the eighteen patients maintained on bromocriptine have shown variable degrees of improvement (Fig. 1). Four patients have shown mild improvement and this was on the basis of some reduction in daily fluctuations and some modest improvement in other Parkinsonian disabilities. In eight patients moderate improvement has been obtained. Four patients have been markedly benefited by bromocriptine. In three cases, there has been complete clearing of previously disabling bradykinesia and end-of-dose deterioration. The remaining case has shown almost complete disappearance of marked ON-OFF fluctuations and dyskinesia.

Significant improvement occurred in various specific Parkinsonian disabilities (Fig. 2).

Of the three non-responders, one has shown no improvement in severe ON-OFF phenomena but has an improved sleep pattern and remains on the drug. The second patient is a severely disabled chronic hospital patient who has shown only some minor improvements in tremor, rigidity and self care. In the third patient the drug was discontinued because of severe confusion (see adverse effects).

Eighteen patients are continuing on bromocriptine in doses ranging from $3.75 \mathrm{mg}$ to $60 \mathrm{mg}$ daily (average 26.3 $\mathrm{mg}$ ). All patients take bromocriptine together with Sinemet on a tid or qid schedule. Sinemet was continued in all of the patients and in 15 patients the dosage was reduced by $125-625 \mathrm{mg}$ daily (average $183.3 \mathrm{mg}$ ). Three patients tolerated no reduction in Sinemet.

Benztropine was discontinued with no loss of function in four of eight patients and resulted in improved mentation in two patients.

Withdrawal of amantadine was attempted in four of eight patients but this led to increased Parkinsonian disabilities and the drug was continued in all patients. Five of the patients with moderate or marked improvement who have been on the drug for 22 months have had some slight deterioration of function in the past few months but remain overall improved compared to the period prior to bromocriptine therapy. This deterioration may be related to the natural progression of their disease.

There were no abnormalities in the multiple hematological and serum biochemical studies or in the urinalyses. Electrocardiograms showed no significant changes. Gynecological examinations have remained normal.

\section{ADVERSE EFFECTS}

Using the method as outlined above, a low incidence of serious adverse effects was encountered (Fig. 3). In five patients pre-existing confusional states and visual hallucinations both showed slight worsening, but responded to medication reduction as follows: Sinemet and bromocriptine reduction (1 case), benztropine and bromocriptine reduction ( 2 cases), and bromocriptine reduction alone ( 2 cases).

Two patients developed more severe mental changes. In one (female, age 64) there was a severe transient agitated psychotic state related to an increase of bromocriptine over a twoweek period from 40 to $60 \mathrm{mg}$ per day 
FIGURE ।

\begin{tabular}{lcc}
\hline $\begin{array}{c}\text { Grade of } \\
\text { Improvement }\end{array}$ & $\begin{array}{c}\text { No. of } \\
\text { Patients }\end{array}$ & $\begin{array}{c}\text { Daily dose range (mg) } \\
\text { of bromocriptine }\end{array}$ \\
\hline None/Unsustained & 2 & $15-45$ \\
Mild & 4 & $5-30$ \\
Moderate & 8 & $12.5-60$ \\
Marked & 4 & $3.75-30$ \\
\hline Overall Results Of Treatment With Bromocriptine (18 Patients)
\end{tabular}

Overall Results Of Treatment With Bromocriptine (18 Patients)

\begin{tabular}{lccc}
\hline $\begin{array}{c}\text { Parkinsonian } \\
\text { disability }\end{array}$ & $\begin{array}{c}\text { Patients } \\
\text { affected }\end{array}$ & $\begin{array}{c}\text { Patients } \\
\text { improved }\end{array}$ & $\begin{array}{c}\text { Daily dose range (mg) } \\
\text { of bromocriptine }\end{array}$ \\
\hline Fluctuations & 15 & 14 & $5-60$ \\
Rigidity & 16 & 12 & $15-60$ \\
Gait disturbance & 15 & 12 & $3.75-60$ \\
Bradykinesia & 11 & 10 & $3.75-60$ \\
Tremor & 9 & 6 & $15-60$ \\
Dyskinesia & 9 & 8 & $3.75-60$ \\
\hline
\end{tabular}

Improvement In Parkinsonian Disabilities With Bromocriptine (18 Patients) coupled with the recent addition of benztropine. Bromocriptine was discontinued for one week, reintroduced at $30 \mathrm{mg}$ daily and the benztropine was stopped. The psychotic state cleared and she remains improved on bromocriptine. In a second patient (female, age 79) two attempts were made with bromocriptine therapy and on each occasion she developed a severe confusional state with hallucinations on dosages of bromocriptine less than $15 \mathrm{mg}$ daily. Bromocriptine was tried with and without concomitant medications (benztropine and amantadine) without any change in the confusional state, and bromocriptine was permanently withdrawn.

One patient with severe ON-OFF phenomena developed a marked increase in dyskinesia with any increase of bromocriptine over $15 \mathrm{mg}$ daily despite significant Sinemet reductions.

Despite prior concern there was no increase in pre-existing postural hypotension in two patients.

\section{DISCUSSION}

Previous studies in the use of bromocriptine in Parkinson's disease have shown variable results. This is probably related to a number of factors including patient selection, different definitions of various disabilities such as ON-OFF phenomena, and variable methods of introduction and use of the drug. Some of the earlier reports have not focused on the method of introducing bromocriptine.

In some studies bromocriptine was used as the sole agent with withdrawal of other drugs, while in others it was used as the initial drug. In those series where bromocriptine was added to pre-existing drug regimes the methods have also varied. Pearce and Pearce (1978) halved the dose of levodopa initially while Lieberman et al. (1979) and Fahn et al. (1979) kept the dose of levodopa stable initially and decreased it as side effects developed following the addition of bromocriptine. Teychenne et al. (1975) started bromo-
FIGURE 3

\begin{tabular}{lccc}
\hline $\begin{array}{c}\text { Adverse } \\
\text { effects }\end{array}$ & $\begin{array}{c}\text { No. of } \\
\text { patients }\end{array}$ & $\begin{array}{c}\text { Daily dose } \\
\text { range (mg) of } \\
\text { bromocriptine }\end{array}$ & $\begin{array}{c}\text { Concurrent } \\
\text { medications, and } \\
\text { (No. of patients) }\end{array}$ \\
\hline $\begin{array}{l}\text { Mild } \\
\text { confusion }\end{array}$ & 5 & $5-60$ & $\begin{array}{l}\text { Sinemet only (2) } \\
\text { Sinemet + benztropine (1) } \\
\text { Sinemet + benztropine } \\
\text { + amantadine (2) }\end{array}$ \\
$\begin{array}{l}\text { Severe } \\
\text { confusion }\end{array}$ & 2 & $15-60$ & $\begin{array}{l}\text { Sinemet + benztropine (1) } \\
\text { Sinemet only. Bromo- } \\
\text { criptine withdrawn (1) }\end{array}$ \\
$\begin{array}{l}\text { Increased } \\
\text { dyskinesia }\end{array}$ & 1 & $>15$ & Sinemet only \\
\hline
\end{tabular}

criptine with $2.5-7.5 \mathrm{mg}$ daily and reduced Sinemet by $125 \mathrm{mg}$ per 5.0-7.5 $\mathrm{mg}$ increase in bromocriptine. Dosages in this latter study were increased to 75 mg per day or until adverse effects developed.

Some series have had a high incidence of serious adverse effects necessitating bromocriptine withdrawal. The drug was discontinued in 31 out of 53 patients by Fahn et al. (1979), in 29 out of 66 patients by Lieberman et al. (1979), and in 29 out of 92 patients by Calne et al. (1978). The most prominent adverse effects in all series have been transient mentation changes which in our experience seem to be fairly easily managed in most patients with adjustment in dosage of bromocriptine or concomitant medications.

Bromocriptine is a relatively difficult drug to introduce and minor drug adjustments often make the difference between success and failure. With the method described here of gradual introduction of bromocriptine and with concomitant slow reduction of Sinemet, bromocriptine had to be permanently stopped in only one patient. Because of the longer duration of action of bromocriptine, many of the patients are able to achieve a tid or qid dosage schedule of Sinemet with bromocriptine, having previously been on a two hourly regime with Sinemet.

Patients with advanced Parkinson's disease are becoming increasingly difficult to manage. New drugs and new approaches are necessary. Bromocriptine has a definite role in the treatment of patients with advanced Parkinson's disease. Careful attention to the details of adding bromocriptine to the drug regime of patients with 
advanced disease will yield a higher number of patients who are able to tolerate the drug with fewer side effects.

\section{ACKNOWLEDGEMENTS}

The authors with to thank their Neurological colleagues Drs. D.M. Atack, R.F. Nelson and D.N. Preston for referring patients for the study. Dr. D.N. Preston also kindly reviewed the manuscript.

Bromocriptine was provided by Sandoz Inc., through the courtesy of Anthony Nalecz, B.Phm.

\section{REFERENCES}

CALNE, D.B., WILLIAMS, A.C., NEOPHYTIDES, A., PLOTKIN, C.,
NUTT, J.G. and TEYCHENNE, P.F. (1978). Long-term treatment of Parkinsonism with bromocriptine. Lancet, 1: 735-738.

FAHN, S., COTE, L.J., SNIDER, S.R., BARRETT, R.E. and ISGREEN, W.P. (1979). The role of bromocriptine in the treatment of parkinsonism. Neurology, 29: 1077-1083.

LIEBERMAN, A.N., KUPERSMITH, M., GOPINATHAN, G., ESTEY, E., GOODGOLD, A. and GOLDSTEIN, M. (1979). Bromocriptine in Parkinson disease: Further studies. Neurology, 29: 363-369.

PEARCE, I. and PEARCE, J.M.S. (1978). Bromocriptine in Parkinsonism. British Medical Journal, 1: 1402-1404.
RASCOL, A., GUIRAUD, B., MONTASTRUC J.L., DAVID, J. and CLANET, M. (1979). Long-term treatment of Parkinson's disease with bromocriptine. Journal of Neurology, Neurosurgery, and Psychiatry, 42: 143-150.

TEYCHENNE, P.F., LEIGH, P.N., REID, J.L., CALNE, D.B., GREENACRE, J.K. and PETRIE, A. (1975). Idiopathic Parkinsonism treated with bromocriptine. Lancet, 2: 473-476. 